\title{
Pembangunan Regional Di Indonesia : Beberapa Catatan Menjelang Abad Ke - 21
}

\author{
Mudrajad Kuncoro
}

\section{I}

ndonesia terkenal sebagai negara kepulauan terbesar di dunia, negara berpenduduk terbanyak ke - 5 di dunia dan ketiga terbesar di Asia. Sekitar 61 persen penduduk Indonesia tinggal di Pulau Jawa dan Bali pada tahun 1990, 20 persen tinggal di Sumatra, dan $19 \%$ di Katimin (Kawasan Timur Indonesia). Tingkat kepadatan penduduknyapun bervariasi dari 70 hingga $180 / \mathrm{km}^{2}$. Boleh dikata tidak ada negara yang begitu beragam seperti Indonesia dalam hal sumber daya alam, demografi, ekonomi, etnik, dan budaya. Ke-Bhinnekaan ini jelas berdampak nyata terhadap kegiatan ekonomi dan sosial di Indonesia. Beberapa daerah amat kaya dengan sumberdaya alam namun jumlah penduduknya relatif jarang. Beberapa daerah telah maju dan makmur, sementara daerah lain masih tertinggal.

Makalah ini akan menyoroti pola pembangunan regional di Indonesia. Pertanyaan yang menarik untuk dikaji lebih lanjut adalah : Bagaimanakah pola pembangunan ekonomi regional selama 28 tahun terakhir? Bagaimana perkembangan kesenjangan ekonomi antar daerah ? Bagaimanakah kesiapan daerah menyambut era otonomi daerah ?

\section{Pola Pembangunan Ekonomi Reglonal} Pembangunan ekonomi regional selama kurang lebih 28 tahun menunjukkan pola sebagai berikut :' Pertama, pertumbuhan ekonomi yang cepat terjadi secara nasional, meskipun laju pertumbuhan amat bervariasi sepanjang waktu dan tidak merata antara propinsi. Pertumbuhan ekonomi nasional selalu tumbuh rata-rata di atas 6 persen per tahun. Ada 10 propinsi yang tingkat pertumbuhannya di bawah rata-rata nasional, dan variasinya antara 9,7 persen (DKI Jakarta) dan 5,7 persen (Sumatra Selatan). Jika migas dikeluarkan dari perhitungan, ada 12 propinsi yang pertumbuhan ekonominya di bawah ratarata nasional.

Kedua, proses transformasi struktural dari pertanian ke industri ternyata berlangsung secara tidak merata dilihat dari dimensi regional. Pada tahun 1968, propinsi yang memiliki pangsa sektor pertanian kurang dari $50 \%$ terhadap PDRB (tanpa migas) hanya ditemukan di 3 propinsi, yaitu Jakarta, Riau, dan Irian Jaya. Pada tahun 1988 terdapat 25 propinsi dengan pangsa sektor pertanian melebihi 50 persen terhadap PDRB. Proses perubahan struktural terjadi dimulai tahun 1993 ketika sumbangan sektor pertanian terhadap PDB anjlok menjadi 20 persen, di mana NTT menduduki peringkat tertinggi (41,5 persen) dalam pangsa sektor pertanian terhadap PDRB, sementara di Jawa dan Bali tinggal 15,8 persen, sedang Kalimantan mencapai 24,5 persen.

Ketiga, dilihat dari sisi PDRB per kapita ternyata tidak terdapat perbedaan

1 Lebih lanjut lihat Ardani (1996: h. 18-20); Hill (1996 : bab 11); World Bank (1996 : bab 4). 
yang mencolok antara propinsi, dengan perkecualian Jakarta dan propinsi penghasil minyak. Sebagai ibukota negara, Jakarta merupakan pusat bisnis dan kegiatan ekonomi Indonesia, dengan kontribusi terhadap PDB meningkat dari 5 persen pada tahun 1968 menjadi 16 persen pada tahun 1990. Produksi migas terkonsentrasi di 4 propinsi, yaitu Aceh, Riau, Sumsel, dan Kaltim. NTT dan NTB merupakan propinsi dengan PDRB per kapita terendah, sekitar Rp. 0;6 juta. Propinsi terkaya Kaltim memiliki PDRB per kapita 16 kali lipat dari propinsi termiskin NTT.

Keempat, dilihat dari konsumsi per kapita sebagai alternatif indikator kesejahteraan regional, propinsi di Indonesia dapat dibagi menjadi 4 kategori, yaitu 2 propinsi yang memiliki konsumsi perkapita tinggi (Jakarta dan Bali masingmasing Rp. 1,5 juta dan Rp. 0,9 juta); 8 propinsi memiliki konsumsi per kapita antara Rp. 0,6 hingga Rp. 0,8 juta (Aceh, Sumut, Sumsel, Riau, Jatim, Kaltim, Kalbar, Kalsel); 12 propinsi dengan konsumsi perkapita antara Rp. 0,4-0,6 juta (Bengkulu, Lampung, Sumut, Jabar, Jateng, DIY, Kalsel, 4 propinsi di Sulawesi, Maluku); dan 4 propinsi dengan konsumsi per kapita Rp 0,3-0,4 juta (NTT, NTB, Timtim, Irja).

Kelima, apabila kinerja pertumbuhan ekonomi daerah dan PDRB per kapita digabungkan maka kita akan mendapatkan kecenderungan pembangunan daerah seperti pada gambar 1. Sumbu vertikal adalah rata-rata PDRB per kapita nonmigas, sedang sumbu horizontalnya adalah rata-rata PDRB per kapita selama periode 1983 - 1990. Disebut "tinggi" bila di atas rata-rata nasional; disebut "rendah" bila di bawah rata-rata nasional. Dengan cara ini kita dapat membagi daerah di Indonesia menjadi daerah : (1) yang pendapatan dan pertumbuhannya tinggi (Riau, Kaltim); (2) yang berpendapatan tinggi namun pertumbuhannya rendah (Aceh, Jakarta, Sumsel, Kalteng, Kalsel);
(3) yang berpendapatan tinggi namun pertumbuhannya tinggi (Irian Jaya, Jatim, Sulteng, DIY, Timtim, Lampung, Sulsel, Maluku, Sumut, Kalbar, Jabar, Jateng, Bali); dan (4) yang berpendapatan dan pertumbuhannya rendah (NTT, NTB, Sulteng, Jambi, Bengkulu, Sulut, Sumbar).

Berdasarkan pola pembangunan regional di atas, tidak dapat dipungkiri bahwa gravitasi aktivitas ekonomi masih berada di Pulau Jawa. Penanaman modal, baik PMA maupun PMDN, pun cendenung terkonsentrasi di pulau Jawa. Oleh karena itu tepat sekali identifikasi Hill (1996) mengenai 2 macam tantangan pembangunan daerah di masa kini dan mendatang, yaitu : Pertama, kesenjangan antara kawasan Timur dan barat Indonesia. Kedua, kemampuan pemerintah (pusat) untuk terus mendanai pembangunan di tiap propinsi setelah turunnya harga minyak.

\section{Kesenjangan Antar Daerah}

Isu kesenjangan ekonomi daerah telah lama menjadi bahan kajian para pakar ekonomi regional. Hendra Esmara (1975) merupakan peneliti pertama yang mengukur kesenjangan ekonomi antar daerah. Berdasarkan data dari tahun 1950 hingga 1960, ia menyimpulkan Indonesia merupakan negara dengan kategori kesenjangan daerah yang rendah apabila sektor migas diabaikan.

Ardani (1996) telah menganalisis kesenjangan pendapatan dan konsumsi antar daerah dengan menggunakan indeks Williamson selama 1968 -1993 dan 1983 1993. Kesimpulannya mendukung hipotesis Williamson (1965) bahwa pada tahap awal pembangunan ekonomi terdapat kesenjangan kemakmuran antar daerah, namun semakin maju pembangunan ekonomi kesenjangan tersebut semakin menyempit. Studi Ardani agaknya sejaian dengan hasil studi Akita dan Lukman (1994) yang menemukan tidak terdapatnya perubahan kesenjangan ekonomi antar daerah selama 1983 - 1990. 
Gambar 1

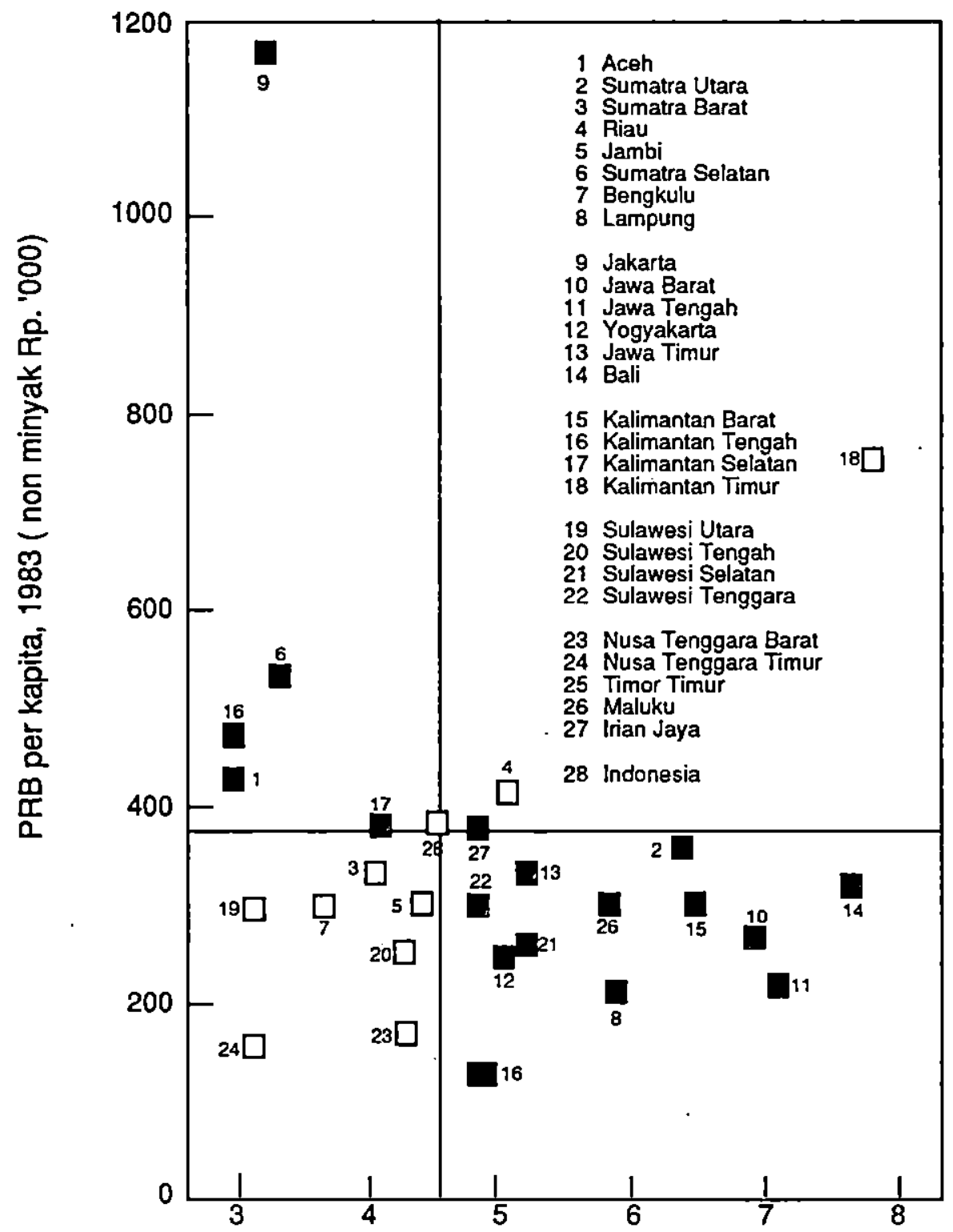

Pertumbuhan rata-rata, PRB perkapita, 1983 - 1990 (nonminyak, \%) 
Dalam konstelasi perkembangan terakhir di Indonesia, kesenjangan ekonomi setidaknya dapat dilihat dari 3 dimensi, yaitu : berdasarkan tingkat kemoderenan, regional, dan etnis (lihat Gambar 2). Pertama, kesenjangan dari tingkat kemoderenan, yaitu kesenjangan antara sektor moderen dan sektor tradisional.
Sektor moderen umumnya, berada di perkotaan dan sektor industri; sedang sektor tradisional umumnya berada di pedesaan dan sektor tradisional. Kedua, kesenjangan regional adalah kesenjangan antara Katimin (kawasan Timur Indonesia) dan Kabarin (Kawasan Barat Indonesia)

\section{Gambar 2}

Peta Kesenjangan Kemakmuran di Indonesia

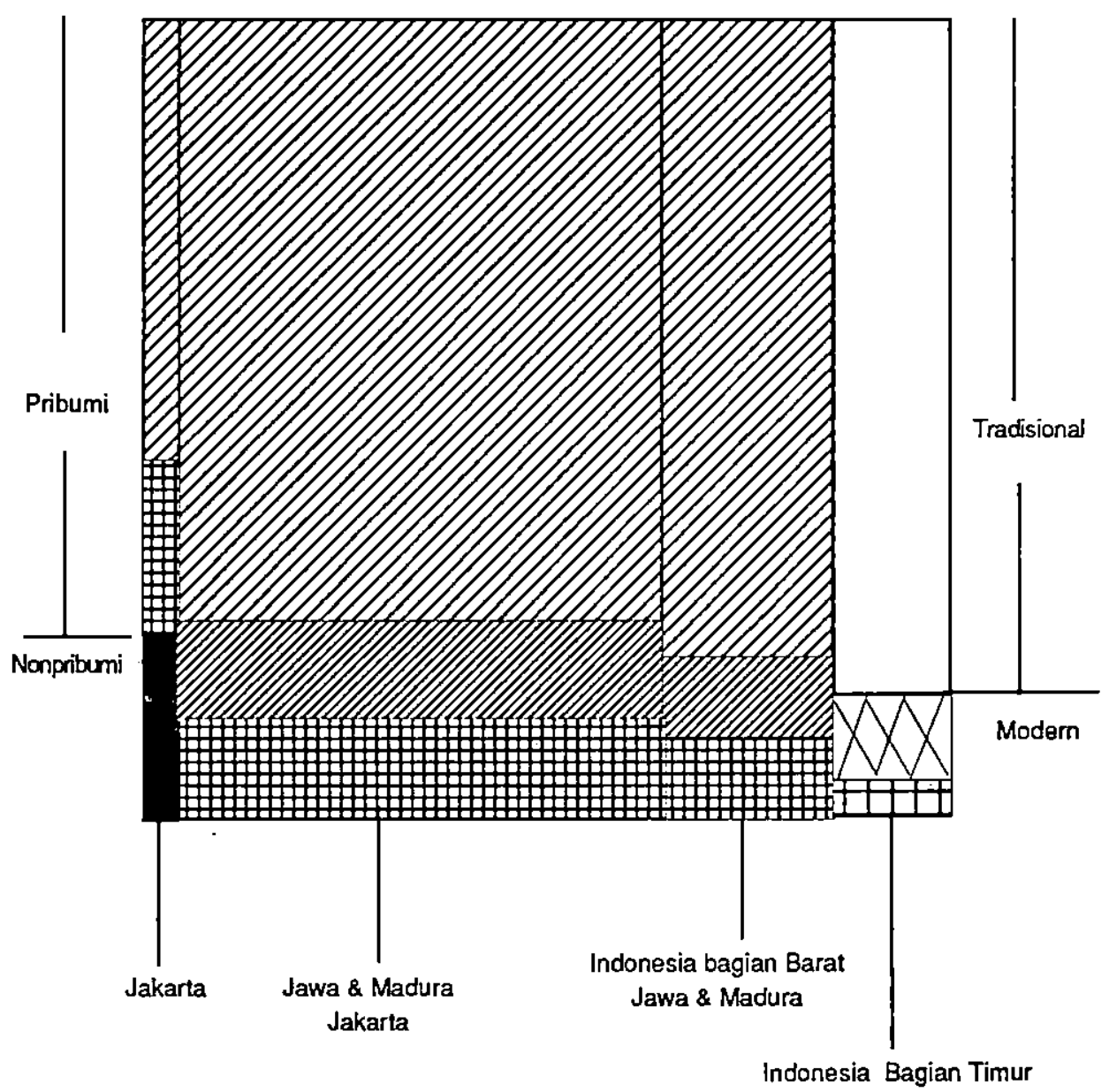

Sumber : Bambang Sudibyo (1990) 
Ketiga, kesenjangan menurut etnis, yaitu antara pribumi dengan nonpribumi.

Apabila ketiga dimensi ini digabungkan maka akan diperoleh potret kesenjangan kemakmuran di Indonesia, yaitu : semakin ke Kabarin maka semakin banyak dijumpai sektor moderen dan industri, dan semakin banyak golongan nonpribumi yang menguasai perekonomian. Sebaliknya semakin ke Katimin, semakin banyak dijumpai sektor pertanian dan tradisional, dan semakin banyak pribumi yang mendominasi usaha bisnis.

Apabila digunakan indikator gini rasio sebagai ukuran ketimpangan distribusi pendapatan, ternyata cukup bervariasi antar propinsi. Secara nasional, gini rasio di perkotaan dan pedesaan cenderung meningkat dari 0,33 pada tahun 1984 menjadi 0,34 pada tahun 1993. Ini berarti secara umum terjadi peningkatan ketimpangan distribusi pendapatan di semua propinsi. Gini rasio yang lebih kecil untuk pedesaan dibanding perkotaan menunjukkan bahwa distribusi pendapatan lebih merata di kawasan pedesaan dibanding perkotaan. Keadaan ini terjadi hampir di seluruh propinsi selama periode 1984-1993.
Pada tahun 1984, angka gini rasio di daerah pedesaan berkisar $0,18-0,33$, dengan catatan gini rasio terendah adalah propinsi Sulsel. Pada tahun 1993, gini rasio pedesaan berkisar antara $0,20-0,30$, dengan rekor terendah dipegang oleh propinsi NTT. Sementara itu, di daerah kota, rentang gini rasio lebih lebar antara 0,21 - 0,42 pada tahun 1984, dengan catatan terendah diraih oleh Jambi. Pada tahun 1993, gini rasio daerah perkotaan berkisar antara $0,24-0,37$, dengan rekor terendah dipegang oleh Jambi dan Maluku.

Potret kesenjangan ekonomi menurut desa-desa agak berbeda dengan potret kemiskinan (lihat Tabel 1). Bila kemiskinan diukur secara absolut, terlihat batas garis kemiskinan di kota lebih tinggi daripada di kota. Ternyata dengan indikator tersebut, jumlah penduduk yang hidup di bawah garis kemiskinan selama 1984 1993 lebih banyak di desa dibanding di kota; persentase penduduk miskin selama 1984-1990 lebih tinggi di kota namun trend ini berbalik pada tahun 1993. Indikator kesenjangan menunjukkan bahwa gini rasio di kota selalu lebih tinggi daripada di desa selama 1984-1994, artinya kesenjangan distribusi pendapatan lebih dirasakan di kota dibanding di desa.

Tabel 1. Kemiskinan dan Distribusi Pendapatan, 1984-1993.

\begin{tabular}{|c|c|c|c|c|c|c|c|c|}
\hline \multirow[t]{2}{*}{ Tahun } & \multicolumn{2}{|c|}{$\begin{array}{l}\text { Batas Garis } \\
\text { Kemiskinan } \\
\text { (Rp/Kapita/bulan) }\end{array}$} & \multicolumn{2}{|c|}{$\begin{array}{l}\text { Presentase } \\
\text { Penduduk } \\
\text { Miskin }\end{array}$} & \multicolumn{2}{|c|}{$\begin{array}{l}\text { Jumlah } \\
\text { Penduduk } \\
\text { Miskin (juta jiwa) }\end{array}$} & \multicolumn{2}{|c|}{ Gini Rasio } \\
\hline & Kota & Desa & Kota & Desa & Kota & Desa & Kota & Desa \\
\hline 1984 & 13.731 & 7.746 & 23,14 & 21,18 & 9,3 & 25,7 & 0,32 & 0,28 \\
\hline 1987 & 17.381 & 10.294 & 20,14 & 16,44 & 9,7 & 20,3 & 0,32 & 0,26 \\
\hline 1990 & 20.614 & 13.295 & 16,75 & 14,33 & 9,4 & 17,8 & 0,34 & 0,25 \\
\hline 1993 & 27.905 & 18.244 & 13,45 & 13,79 & 8,7 & 17,2 & 0,33 & 0,26 \\
\hline
\end{tabular}

Sumber : BPS (1994) 


\section{Menuju Era Otonoml Daerah}

Tanggal 25 April 1995, sejarah mencatat dimulainya pencanangan proyek uji coba otonomi daerah oleh Presiden Soeharto dengan nama program Pemantapan Daerah Percontohan Otonomi untuk 26 Dati II. Bagi Pemda, tentunya ini merupakan saat yang dinantinanti. Betapa tidak. Usia UU Nomor 5 tahun 1974 tentang Pokok-pokok Pemerintahan Daerah sudah genap 22 tahun. Artinya secara de jure sudah ada kemauan politik untuk mengimplementasikan desentralisasi politik (otonomi) dan desentralisasi administratif (dekonsentrasi) sejak tahun tersebut. Hanya uniknya, baru pada tahun 1992 keluar Peraturan Pemerintah No. 45 Tahun 1992 tentang penyelenggaraan otonomi daerah dengan titik berat Dati II sebagai jawaban atas kritik masyarakat bahwa pelaksanaan otonomi daerah masih tersendat-sendat dan semu.

Bahwa titik berat desentralisasi dan otonomi di Indonesia adalah Daerah Tingkat II (Dati II) agaknya mudah dipahami. Pertama, dari dimensi politik, Dati II dipandang kurang mempunyai fanatisme kedaerahan sehingga resiko gerakan separatisme dan peluang berkembangnya aspirasi federalis relatif minim. Kedua, dari dimensi adiministratif, penyelenggaraan pemerintahan dan pelayanan kepada masyarakat relatif dapat lebih efektif. Ketiga, Dati II adalah daerah "ujung tombak" pelaksanaan pembangunan sehingga Dati II-lah yang lebih tahu kebutuhan dan potensi rakyat di daerahnya. Pada gilirannya, yang terakhir ini dapat meningkatkan local accountability Pemda terhadap rakyatnya. Atas dasar itulah prinsip otonomi yang dianut, , yaitu otonomi yang nyata, bertanggung jawab dan dinamis, diharapkan dapat lebih mudah direalisasikan. Akibat prinsip-prinsip ini, dikenal adanya daerah otonom dan wilayah administratif. Daerah Tingkat I atau Tingkat II sebagai sebutan daerah otonom sering didentikkan dengan Propinsi atau Kabupaten yang merupakan wilayah ad- ministratif.

Masalahnya kini, meskipun harus diakui bahwa UU No. 5/1974 adalah suatu komitmen politik, namun dalam praktek yang terjadi adalah sentralisasi (baca : kontrol dari pusat) yang dominan dalam perencanaan maupun implementasi pembangunan Indonesia. Salah satu fenomena paling menonjol dari hubungan antara sistem Pemda dengan pembangunan adalah ketergantungan Pemda yang tinggi terhadap pemerintah pusat. Ketergantungan ini terlihat jelas dari aspek keuangan, Pemda kehilangan keleluasaan bertindak (local discretion) untuk mengambil keputusan-keputusan penting, dan adanya. campur tangan pemerintah pusat yang tinggi terhadap Pemda.

Dalam konstelasi semacam ini, amat menarik tulisan Frans Seda (Kompas, 8 April 1996), yang menyatakan UU No. $5 /$ 1974 dinamakan "..... Undang-undang yang membuldozer otönomi daerah". Argumennya, mengacu pada penjelasan pasal 18 UUD 1945, bahwa prinsip-prinsip otonomi adalah hak dari masyarakat di daerah atas kemandirian dan hukum/adat setempat dalam mengembangkan potensi sosial, ekonomi, dan budayanya. Karena itu, ia merasa aneh apabila mendengar otonomi sepertinya hadiah daripusat dan daerah-daerah perlu membuktikan kemampuan mereka, sehingga perlu dilakukan uji coba. Lebih lanjut dikatakan, bahwa fokus otonomi daerah di Indonesia adalah desentralisasi kekuasaan/ kewenangan Pemerintah kepada- suatu wilayah pemerintahan.

Tidak berlebihan bila banyak yang berpendapat sejauh ini upaya desentralisasi di Indonesia diletakkan dalam kerangka sentralisasi. Tepat sekali pernyataan Sumitro Maskun, Dirjen PUOD, bahwa "Sebenarnya otonomi yang diterapkan di Indonesia adalah otonomi yang datang dari atas" (GATRA, No. 13/ 1995). Pembangunan daerah tenutama fisik memang cukup pesat, tetapi tingkat 
ketergantungan fiskal antara daerah terhadap pusat sebagai akibat dari pembangunan tersebut juga semakin besar. Ketergantungan tiskal terlihat dari relatif rendahnya PAD dan dominannya transfer dari Pusat. Memang UU No. 5 tahun 1974 telah menggarisbawahi titik berat otonomi pada Daerah Tingkat II. Namun, fakta menunjukkan justru Dati IIlah yang mengalami tingkat ketergantungan yang paling tinggi ${ }^{2}$. Faktor penyebab utama ketergantungan fiskal di Indonesia, setidaknya meliputi : (1) kurang berperannya perusahaan daerah sebagai sumber pendapatan daerah; (2) tingginya derajat sentralisasi dalam bidang perpajakan; (3) kendati pajak daerah cukup beragam ternyata hanya sedikit yang bisa diandalkan sebagai sumber penerimaan; (4) adanya kekhawatiran apabila daerah mempunyai sumber keuangan yang tinggi maka ada kecenderungan terjadi disintegrasi dan separatisme; kelemahan dalam pemberian subsidi.

Kendati demikian, Pemda telah berperan sentral dalam ikut menyukseskan pembangunan infrastruktur dan pelayanan sosial, serta telah berfungsi sebagai 'alat' pusat yang efektif dalam mendorong pembangunan daerah. Dengan kata lain, obsesi pembangunan ekonomi ke seluruh daerah Indonesia telah mendorong pemerintah pusat untuk melakukan kontrol politik dan ekonomi terhadap pemerintah daerah. Justifikasi yang biasanya diajukan adalah stabilitas politik merupakan prasyarat mutlak bagi lancarnya pembangunan. Tak pelak lagi, sentralisasi hubungan pusat-daerah lebih mencuat ke permukaan meskipun desentralisasi secara de jure sudah didendangkan sejak awal tahun 1970-an.

\section{Mencari Format Otonomi Daerah}

Bisa dipahami mengapa para petinggi daerah begitu antusias menyambut proyek uji coba otonomi. Hanya saja, masih banyak yang mempertanyakan format otonomi daaerah yang bagaimana yang akan diwujudkan? Setidaknya ada beberapa pertanyaan mendasar yang perlu dipikirkan dalam upaya mencari format otonomi daerah Indonesia.

Pertama, apakah wewenang yang diberikan kepada Pemda hanyalah wewenang dalam bidang administrasi ataukah juga diikuti oleh wewenang dalam bidang fiskal (keuangan) ? Ada tendensi kuat, otonomi administrasi lebih menonjol dibanding otonomi keuangan. Penyerahan urusan (baca : wewenang) kepada daerah agaknya dengan lancar akan terjadi, terutama di daerah yang dijadikan proyek percontohan otonomi daerah. Hanya masalahnya, bagaimana mungkin membiayai otonomi bila selama ini subsidi/ bantuan pusat masih jauh lebih besar dibanding Pendapatan Asli Daerah (PAD) ? Memang mudah menyerahkan tugas kepada daerah. Namun tidak mudah menyerahkan sumber-sumber "gemuk" yang selama ini ditarik ke pusat untuk dialihkan, sebagian atau seluruhnya, kepada daerah. Agaknya Rancangan UU Perimbangan Keuangan Pusat Daerah, yang konon masih ada di laci Sekneg' Depkeu, sudah saatnya untuk dikeluarkan guna mengganti UU Perimbangan Keuangan produk tahun 1950-an, yaitu UU No. 32 tahun 1956 dan UU Darurat No. 11 dan 12 tahun 1957. Departemen Keuangan dan Departemen Dalam Negeri agaknya menyadari urgensi masalah ini, sehingga tanggal 25 hingga 27 September 1996 ini mengadakan lokakarya di Jambi dengan topik "Peningkatan Kemampuan Keuangan Daerah melalui Rasionalisasi Pungutan Daerah".

Kedua, bagaimana bisa berbicara otonomi apabila bantuan spesifik (specific grants), yang penggunaannya diatur dengan ketat oleh pusat, masih lebih besar dibanding bantuan blok (block grants) ? Subsidi yang bersifat blok terdiri dari Inpres Dati I, Inpres Dati II, dan Inpres Desa. Subsidi yang bersifat spesifik meliputi Inpres pengembangan wilayah, Sekolah 
Dasar, kesehatan, penghijauan dan reboisasi, serta jalan dan jembatan. Perbedaan utama antara subsidi blok dengan subsidi spesifik adalah bahwa daerah memiliki keleluasaan dalam penggunaan dana subsidi blok; sedang penggunaan dana subsidi spesifik sudah ditentukan oleh pemerintah pusat dan daerah tidak punya keleluasaan dalam menggunakan dana tersebut. Bila program otonomi daerah benar-benar mau direalisasikan, hendaknya bantuan yang bersifat blok lebih tinggi porsinya dibanding bantuan spesifik.

Ketiga, apabila subsidi merupakan alat yang tidak mungkin ditiadakan (karena alasan negara kesatuan, misalnya), bagaimana mendesain alokasi subsidi dari pusat yang mampu mengakomodasi kebutuhan daerah ? Pengamatan terhadap program-program Inpres menunjukkan bahwa program tersebut merupakan upaya untuk mendesentralisasi beberapa fungsi pemerintah pusat, terutama implementasi pembangunan infrastruktur, kepada jenjang pemerintahan yang lebih rendah. Memang, program Inpres merupakan instrumen kebijakan yang penting untuk mengatasi masalah ketimpangan antar daerah dan kendala birokratis untuk memperkuat kapasitas Pemda. Kendati demikian, beberapa studi menemukan bahwa program inpres hanya secara parsial mampu menjawab masalah tersebut.

Besar kemungkinan yang terakhir ini disebabkan oleh beberapa masalah berikut ini : Pertama, dalam pengalokasian dana inpres boleh dikata kecil sekali dipertimbangkan berbagai kebutuhan daerah. Kedua, transfer dana dari pusat mengabaikan perbedaan kemampuan daerah dalam membiayai pembangunan dari sumber-sumber asli daerah. Ketiga, disain dana dari pusat tidak mendorong daerah untuk meningkatkan PAD maupun meningkatkan pinjaman daerah.

Keempat, pemberian otonomi apakah dapat membuat aparat birokrasi
Pemda semakin efisien dan efektif dalam menjalankan tugasnya? Selama ini, aparat Pernda mengeluh karena tugas "titipan" dari pusat amat banyak. Ibaratnya, dari daun jatuh hingga orang mati menjadi tanggung jawab mereka. Kesimpangsiuran tugas dan pembiayaannya agaknya sudah saatnya dikoordinasikan antara kantor MenPan, Mendagri, dan Menkeu.

Kelima, bagaimana peran Kepala Daerah (Bupati dan Walikota) dalam menggerakkan dan mendayagunakan potensi sumberdya dan sumberdana daerah ? Dalam konteks ini, usulan David Osborne dan Ted Gaebler (1993) untuk mengembangkan entrepreneurial spirit dalam sektor publik sebagai upaya reinventing goverment sungguh menarik untuk kita simak. Menurut mereka, semangat wirausaha tidak hanya dikonotasikan dengan pelaku bisnis tapi juga amat mungkin diterapkan bagi para pelaku di birokrasi dan lembaga pemerintah lainnya. Seorang 'wirausaha selalu berupaya menggunakan sumberdaya dengan cara yang baru untuk memaksimalkan produktivitas dan efektifitas.

Dalam konteks pemerintahan daerah, semangat wirausaha dapat diwujudkan dengan mengubah gaya manajemen yang hirarkis-birokratis menjadi gaya manajemen yang lebih partisipatif (participatory management dan teamwork organization). Ini dapat dilakukan dengan : (1) menciptakan manajemen yang lebih mendukung inovasi dari bawah; (2) struktur yang tidak ketat/kaku; (3) lebih banyak memberi masukan daripada meminta masukan kepada pengambil keputusan; (4) otonomi pengambilan keputusan dan perencanaan yang lebih tinggi; dan (5) bekerja dalam satu lingkungan tim kerja yang solid.

Keenam, bagaimana format kerjasama Kepala Daerah dengan DPRD dalam kerangka otonomi ? Pemda di Indonesia, yang meliputi DPRD dan Kepala Daerah, adalah institusi yang -melayani 
masyarakat sekaligus merupakan institusi politik. Karena penguasa daerah termasuk organisasi sektor publik, segala keputusannya selalu berdasarkan pertimbangan politik. Ini berarti keperluan dan desain suatu pendekatan manajemen baru dalam Pemda harus mempertimbangkan : (1) suatu pendekatan dan pemikiran yang baru mengenai manajemen Pemda; (2) manajemen yang mendukung proses politik; (3) kepentingan daerah (local choice) yang mencerminkan pilihan nilai dan sanggup merespon aspirasi penduduk daerah.

Akhirnya, program percontohan yang sudah dicanangkan Kepala Negara hendaknya didukung oleh semua pihak tidak hanya Pemda namun juga departemen dan para pejabat di pusat. Perlu digarisbawahi, otonomi hanyalah sekedar alat bukan tujuan bagi pembangunan daerah maupun upaya menuju local democracy. Penegasan Presiden Soeharto bahwa otonomi daerah tidak merupakan resiko bagi negara kesatuan Rl amat menarik untuk disimak. Karena itu tepat sekali pesan dan keinginan Presiden bahwa otonomi daerah justru akan lebih mengembangkan dan mengukuhkan akar demokrasi Pancasila.

\section{Daftar Pustaka}

Ardani, Amiruddin (1996), Regional Development in Indonesia: Issues and Challenges, Discussion Paper No. 36, Nagoya University, Nagoya, July.

Biro Pusat Statistik (1994), Laporan Perekonomian Indonesia 1993, Jakarta, Maret.

Esmara, Hendra (1975), "Regional Income Disparities", Bulletin of Indonesian Economic Studies, 11 (1), h. 41-57. Hill, Hal (1996), Transformasi Ekonomi In- donesia Sejak 1966 : Sebuah Studi Kritis dan Komprehensif, PAU Studi ekonomi UGM dan PT Tiara Wacana Yogya, Yogyakarta.

Iskandar, Dono D., (1993), "Masalah dan Prospek Pembiayaan Pembangunan Daerah", makalah dalam Sidang Pleno ISEI VII Pendanaan Pembangunan: Pelauang dan Tantangar, Jakarta : ISEl.

Kuncoro, Mudrajad (1993), "The Political Economy of Decentralizaiton in Indonesia, Towards Cultivating the Grass-roots?". The Indonesian Quarterly, no. 3, h. 344-58.

(1994), "Manajemen Pembangunan dalam PJPT. II : Menuju Desentralisasi?", Manajemen dan Usahawan Indonesia, no. 4, April, h. 8-12.

(1995), "Desentralisasi Fiskal di Indonesia : Dilema Otonomi dan Ketergantungan", Prisma, no. 4, April, h. 3-18.

MacAndrews, Colin (ed.) (1986) Central Government and Local Development in Indonesia. Singapore : Oxford University Press.

Ohmae, Kenichi (1995). The End of the Nation State: The Rise of Regional Economies, McKinsey \& Company Inc.

Osborne, David dan Ted Gaebler (1993), Reinventing Government: How the Entrepreneurial Spirit is Transforming the Public Sector, New York : A Plume Book.

Sumitro (1989) Desentralisasi Dalam Pelaksanaan Manajemen Pembangunan, Jakarta : Pustaka Sinar Harapan.

World Bank (1996), Indonesia Dimension of Growth, Country Departement IIIEast Asia and Pasific Region, 7 Mei. 